\title{
Bibliometric Analysis of the Term 'Zakat'
}

\author{
Muhammad Syariful Anam ${ }^{1 *}$, Pandu Nur Wicaksono ${ }^{1}$, Rina Rosia $^{1}$ \\ ${ }^{1}$ Faculty of Islamic Economics and Business, IAIN Salatiga, Indonesia
}

\begin{abstract}
This study aims to determine the development of research on zakat from 2009 to 2021 . The articles were obtained using the Publish or Perish (PoP) software on the Scopus database. By scanning using Scimagojr (Q1, Q2, and Q3), this study analyzed 79 articles from 41 reputable journals. In addition, Mendeley software is used to complete article metadata. This study uses a literature review method with bibliometric analysis using VOSviewer software. The results of the analysis show that the number of articles on zakat published in reputable journals has increased, especially in the last four years. Then, the keywords that often appear in research on zakat are 'zakat', 'zakat institution', 'Islam', and 'poverty'. Meanwhile, research on zakat with the keyword 'compliance', 'financial inclusion', 'performance', and 'social capital' is still little studied so that it has the opportunity to be researched in the future.
\end{abstract}

\section{Introduction}

Zakat is the third of the five pillars of Islam that all Muslims in the world must obey, and is one of the fiscal tools used since the time of the Prophet Muhammad to alleviate poverty and reduce income inequality by redistributing wealth from the rich to the poor. (Ahmed \& Salleh, 2016; Aziz \& Mohamad, 2016; Samad \& Glenn, 2010). According to Qardhawi (2011) in etymology zakat has several meanings, namely ath-thaharatu which means purity, al-barakatu which means blessing, ash-shalahu which means goodness, and al-namaa which means growth and development. In the Qur'an at-Taubah: 60, Allah SWT has determined eight groups of people who are entiteld to receive zakat:

"Actually, zakat is only for the needy, the poor, zakat administrators, converts who are persuaded by their hearts, to (liberate) slaves, people who are in debt, for the way of Allah, and for those who earn. is on the way, as a statute ordained by Allah, and Allah is All-Knowing, All-Wise".

Based on the results of the World Population Review (2021), the Muslim population makes up 26 percent of the total global population, equivalent to 1.9 billion people worldwide. This encourages the potential amount of world zakat to reach USD 500-600 annually (Beik, 2020). Therefore, if zakat management is optimal, zakat can be a good instrument in alleviating poverty. More than that, it can be used as community empowerment and wealth distribution.

The high development of zakat in various countries has an impact on the extent of research on zakat literature conducted by researchers. As for several researchers who have

\footnotetext{
* Corresponding author: syarifulanam2700@gmail.com
} 


\section{$A \overline{I E B} \quad$ Annual International Conference \\ on Islamic Economics and Business, 2021}

conducted studies on zakat, namely Rusydiana \& As-salafiyah (2021) who conducted a bibliometric study of the role of zakat in the Covid-19 pandemic. Another bibliometric analysis was also carried out by Nor Paizin et al. (2021) who reviewed research on zakat from the Scopus database. In addition, Hudaefi \& Beik (2020) also researched digital zakat campaigns during the Covid-19 outbreak using a netnographic approach.

Based on the background, this study aims to find out the map of the development of research on one of the Islamic philanthropic instruments, namely zakat from 2009 to 2021. This bibliometric study is important to do in order to map research on zakat and also to advise researchers on issues related to zakat. Issues in the field of zakat that need to be researched in the future. The novelty in this research is to use articles about zakat from reputable journals indexed by Scopus.

\section{Method}

This study uses a literature review method with bibliometric analysis which aims to determine the development of research on zakat in reputable international journals. The data used in this study were sourced from the Scopus database which was obtained with the help of Publish or Perish (PoP) software. The literature search was conducted on 19 November 2021 using the keyword 'Zakat'. The search was devoted to 'journal', 'title word only', and year '0-0'. Based on the initial search results from the Scopus database, 176 articles were obtained for the period 2003 to 2021.

After the initial search process, the 176 articles were then downloaded in RIS format and imported into Mendeley software. Mendeley is used to filter and refine article metadata, such as title, author, journal name, abstract, and keywords. Meanwhile, article screening was determined based on the criteria as listed in Table 1. Of the 176 articles from the initial search results, we only used 79 articles from reputable journals (Q1, Q2, and Q3) based on the Scimagojr website. Meanwhile, the selected time period is from 2009 to 2021, we did not use articles published in 2003 because the articles did not meet the screening criteria. The 79 articles were then carried out bibliometric analysis using VOSviewer software. VOSviewer is a computer program developed to create, visualize, and view bibliometric maps (van Eck \& Waltman, 2010).

Table 1. Article Screening Criteria

\begin{tabular}{|c|c|}
\hline Screening Criteria & Number of Article \\
\hline No english & 1 \\
\hline Book review & 1 \\
\hline Q4/Not registered by Scimagojr & 95 \\
\hline $\mathrm{Q} 1 / \mathrm{Q} 2 / \mathrm{Q} 3$ & 79 \\
\hline Total & 176 \\
\hline
\end{tabular}

\section{Result and Discussion}

\subsection{Trends in Number of Publications per Year}

Based on data obtained from the Scopus database, the trend in the number of research publications on the topic of zakat from 2009 to November 2021 tends to increase (see Fig 1). The number of research publications on zakat from 2009 to 2017 , has not shown a significant trend. However, from 2018 to 2021, research publications on zakat have increased dramatically, even 2021 being the year with the highest number of research publications on zakat, reaching 24 documents. This shows that research on zakat is starting to get attention 


\section{$A I C \overline{I F B}$ Annual International Conference \\ on Islamic Economics and Business, 2021}

from academics, so research on the topic of zakat has a large enough opportunity to continue to be researched in the future.

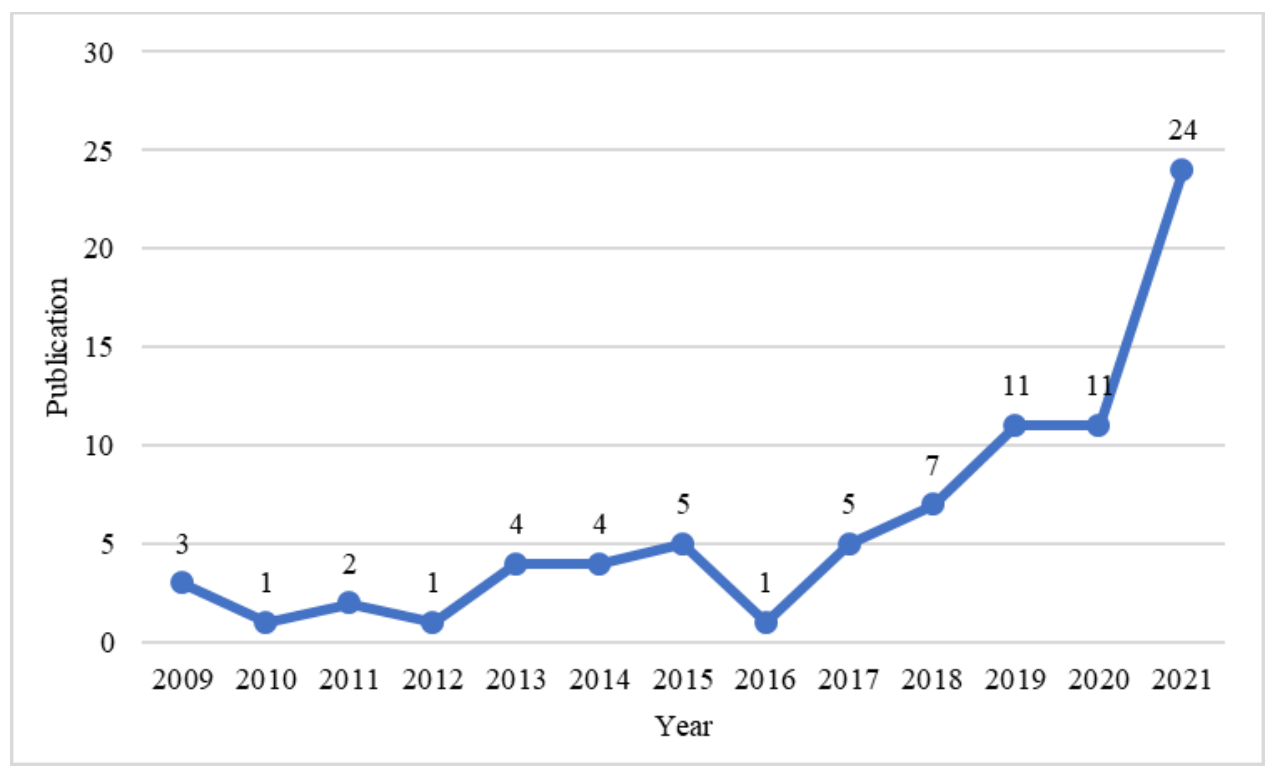

Fig 1. Trends in Number of Publication per Year

\subsection{Core Journal}

Of the 79 articles that study zakat, 41 have been published in reputable journals (Q1, Q2, and Q3). Based on Table 2, 41 journals found 4 core journals that publish the most research articles on the topic of zakat. The 'Journal of Islamic Accounting and Business Research' (Q3) is the journal that publishes the most research articles in the field of zakat with a total of 16 documents. In second place is the 'International Journal of Islamic and Middle Eastern Finance and Management' (Q2) with a total publication of 10 documents. This was followed by the 'Journal of Economic Cooperation and Development' (Q3) and 'ISRA International Journal of Islamic Finance' (Q2) by publishing 5 and 4 documents, respectively.

Table 2. Core Journal

\begin{tabular}{|l|c|}
\hline \multicolumn{1}{|c|}{ Journal Name } & Document \\
\hline Journal of Islamic Accounting and Business Research & 16 \\
\hline International Journal of Islamic and Middle Eastern Finance and Management & 10 \\
\hline Journal of Economic Cooperation and Development & 5 \\
\hline ISRA International Journal of Islamic Finance & 4 \\
\hline
\end{tabular}

\subsection{Co-Author Network}

Co-authorship analysis based on the author's name was carried out using VOSviewer software. Co-authorship analysis is used to identify collaborations between authors and help to build future research collaborations (Bindu et al., 2019). As can be seen in Fig 2, it shows that Ram Al Jaffri Saad is the author with the most collaboration groups, followed by Kazi Sohag, Muhamad Abduh, Norazlina Abd. Wahab, and Nature Painting. In addition, Ram Al Jaffri Saad is also the most prolific writer with a total of 6 research publications on zakat. Visualization of co-authorship can be used to determine the collaboration trend of each 


\section{$A I C \overline{I E B}$ Annual International Conference \\ on Islamic Economics and Business, 2021}

author, and encourage writers who still lack collaboration to increase their collaboration with other authors.

\& vosviewer

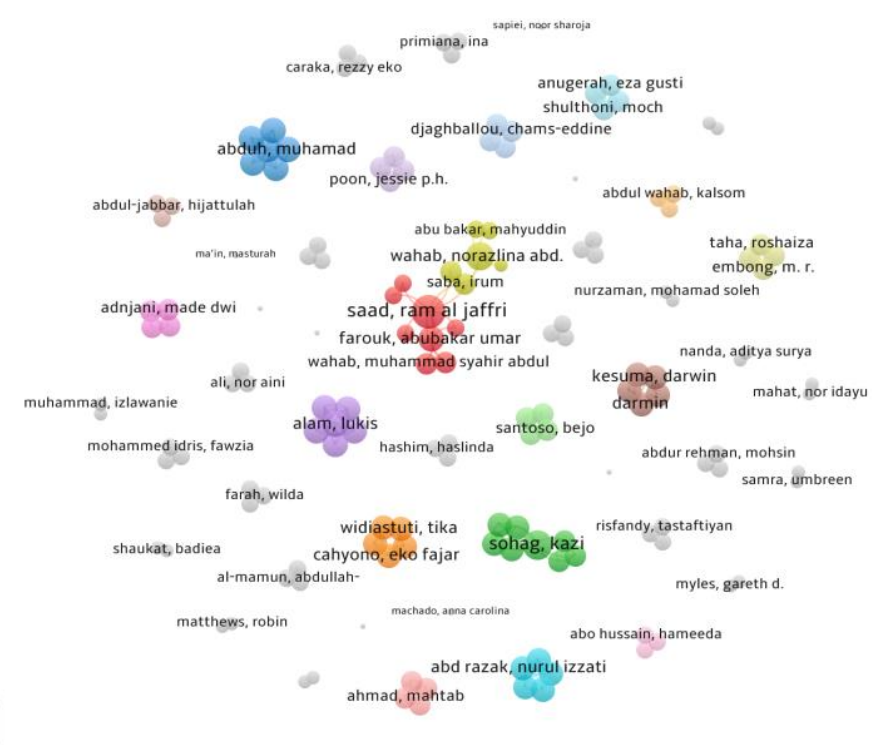

Fig 2. Co-Author Network (Minimum 2 Documents)

\subsection{Number of Author Citations}

Table 3 is a summary of the articles on zakat that are most frequently cited. This analysis is based on search results using PoP software. From all authors, it is determined by the number of citations from authors who have more than 15 citations. Article was written by Wahab \& Rahim Abdul Rahman (2011) with the title "A framework to analyze the efficiency and governance of zakat institutions" is the article with the most citations with a total of 53 citations. The next article was written by Mohit \& Nazyddah (2011) with the title "Social housing program of the Selangor Zakat Board of Malaysia and housing satisfaction" ranked second with 32 citations. Then, the article entitled "Decisions on capital structure in a Zakat environment with the prohibition of usury: The case of Saudi Arabia" written by Al-Ajmi et al. (2009) ranks third with a total of 24 citations.

Article written by Wahab \& Rahim Abdul Rahman (2012) with the title "Efficiency of Zakat Institutions in Malaysia: An Application of Data Envelopment Analysis" was ranked fourth with a total of 19 citations. Next, an article with the title "Accounting treatment for corporate zakat: a critical review" written by Akhyar Adnan \& Barizah Abu Bakar (2009) is in fifth place with a total of 18 citations. Lastly, the article was written by Sohag et al. (2015) with the title "Can Zakat System Alleviate Rural Poverty in Bangladesh? A Propensity Score Matching Approach" has been cited as many as 17 citations. 
Table 3. Number of Author Citations

\begin{tabular}{|l|l|c|}
\hline \multicolumn{1}{|c|}{ Author } & \multicolumn{1}{|c|}{ Title } & Citation \\
\hline $\begin{array}{l}\text { Wahab, N. A., } \\
\text { \& Rahim Abdul } \\
\text { Rahman, A. }\end{array}$ & $\begin{array}{l}\text { A framework to analyse the efficiency and governance of zakat } \\
\text { institutions }\end{array}$ & 53 \\
\hline $\begin{array}{l}\text { Mohit, M. A., \& } \\
\text { Nazyddah, N. }\end{array}$ & $\begin{array}{l}\text { Social housing programme of Selangor Zakat Board of Malaysia } \\
\text { and housing satisfaction }\end{array}$ & 32 \\
\hline $\begin{array}{l}\text { Al-Ajmi, J., } \\
\text { Abo Hussain, } \\
\text { H., \& Al-Saleh, } \\
\text { N. }\end{array}$ & $\begin{array}{l}\text { Decisions on capital structure in a Zakat environment with } \\
\text { prohibition of riba: The case of Saudi Arabia }\end{array}$ & 24 \\
\hline $\begin{array}{l}\text { Wahab, N. A., } \\
\text { \& Rahim Abdul } \\
\text { Rahman, A. }\end{array}$ & $\begin{array}{l}\text { Efficiency of Zakat Institutions in Malaysia: An Application of } \\
\text { Data Envelopment Analysis }\end{array}$ & 19 \\
\hline $\begin{array}{l}\text { M., \& Barizah Adnan, } \\
\text { Abu Bakar, N. }\end{array}$ & Accounting treatment for corporate zakat: a critical review & 18 \\
\hline $\begin{array}{l}\text { Sohag, K., } \\
\text { Mahmud, K. T., } \\
\text { Alam, F., \& } \\
\text { Samargandi, N. }\end{array}$ & $\begin{array}{l}\text { Can Zakat System Alleviate Rural Poverty in Bangladesh? A } \\
\text { Propensity Score Matching Approach }\end{array}$ & 17 \\
\hline
\end{tabular}

\subsection{Network Visualization Map and Overlay}

The results of the network visualization of the co-word map of the development of research on zakat are divided into 10 clusters (see Fig 3). Cluster 1 consists of 5 subjects, namely 'performance', 'social capital', 'trust', 'zakat compliance', and 'zakat institution'. Cluster 2 consists of 4 subjects, namely 'financial inclusion', 'Islamic finance', 'zakat', and 'zakat collection'. Cluster 3 consists of 3 subjects, namely 'capital structure', 'Islam', and 'taxes'. Cluster 4 consists of 3 subjects, namely 'confidence', 'government', and 'zakat management'. Cluster 5 consists of 3 subjects, namely 'compliance', 'religiosity', and 'theory of reasoned action'. Cluster 6 consists of 2 subjects, namely 'economic development, and 'economic growth'. Cluster 7 consists of 2 subjects, namely 'poverty' and 'social welfare'. Cluster 8 consists of 2 subjects, namely 'tax rebate', and 'theory of planned behavior'. Cluster 9 consists of 1 subject, namely 'accountability'. And cluster 10 consists of 1 subject, namely 'efficiency'.

Each cluster has a different number of subjects or keywords. This shows that research on zakat is very varied. If seen in Fig 3, most subjects are in cluster 1, meaning that the themes in that cluster get more attention from researchers. In other words, keywords that are in cluster 1 get more attention in research on zakat. 


\section{\& vosviewer}

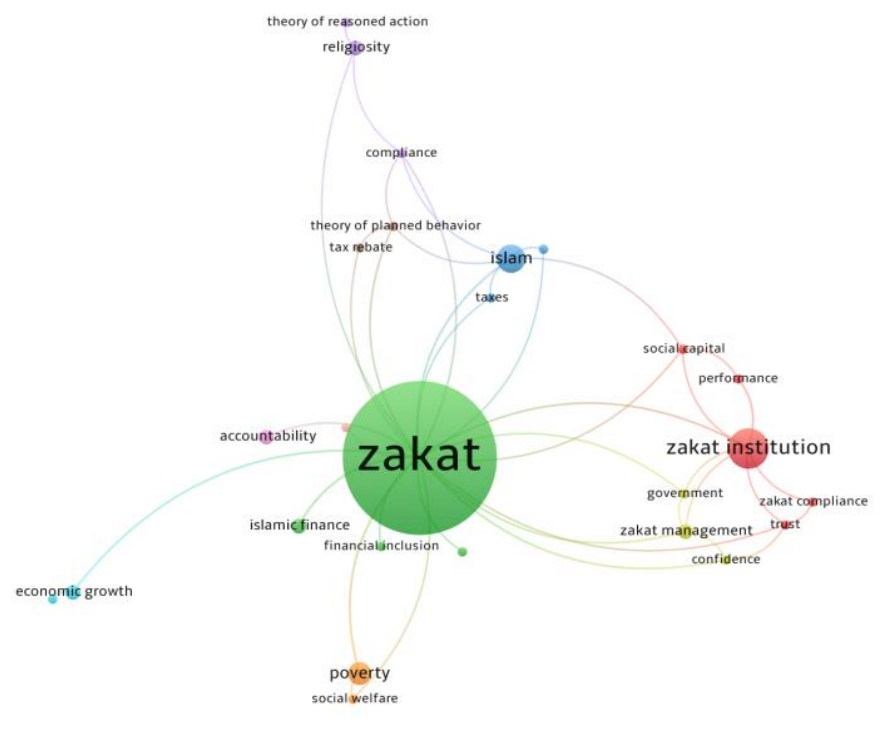

Fig 3. Network Visualization

In addition, this study also maps the year each keyword frequency that appears frequently. Based on Fig 4, it can be seen that the frequency of keywords that appear frequently and have a correlation with other research occurs in the range of 2014 to 2021. From Fig 5 there are also three colors, namely purple, green, and yellow. These colors indicate that the closer to purple the color means that the topic has been researched for a long time, on the contrary, if it is closer to yellow, it indicates that the topic is still being researched.

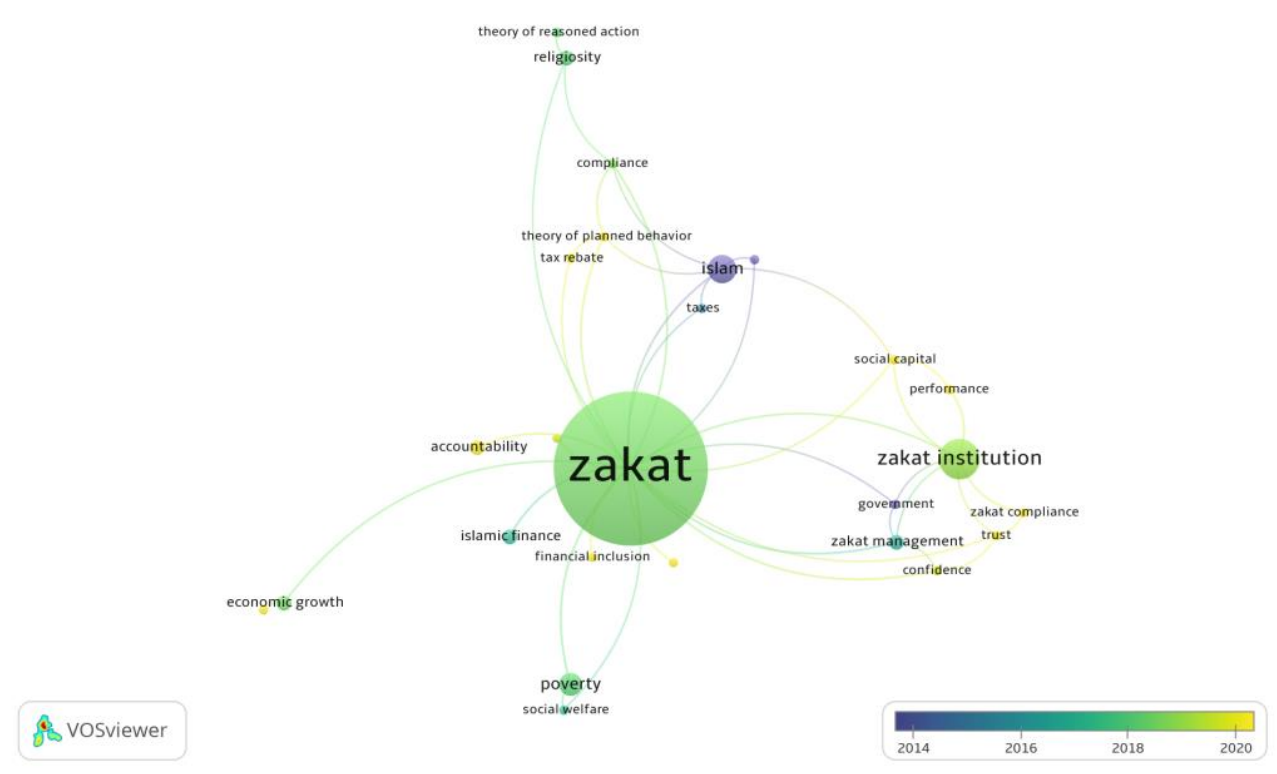

Fig 4. Overlay Visualization 


\section{$A \mathrm{I} \overline{I E B}$ Annual International Conference \\ on Islamic Economics and Business, 2021}

\subsection{Density Map Visualization}

A density visualization map is used to see the depth of keywords that are often used in research on zakat. As can be seen in Fig 5, the lightest color indicates that the topic has been researched frequently. Meanwhile, the light color indicates that the topic is still rarely studied so that the topic still has the opportunity to be researched in the future. Based on the density map, the keywords that appear or are most frequently researched are 'zakat', 'zakat institution', 'Islam', and 'poverty'. Meanwhile, research on zakat with the keywords 'compliance', 'financial inclusion', 'performance', and 'social capital' is still little studied so that it has the opportunity to be researched in the future.

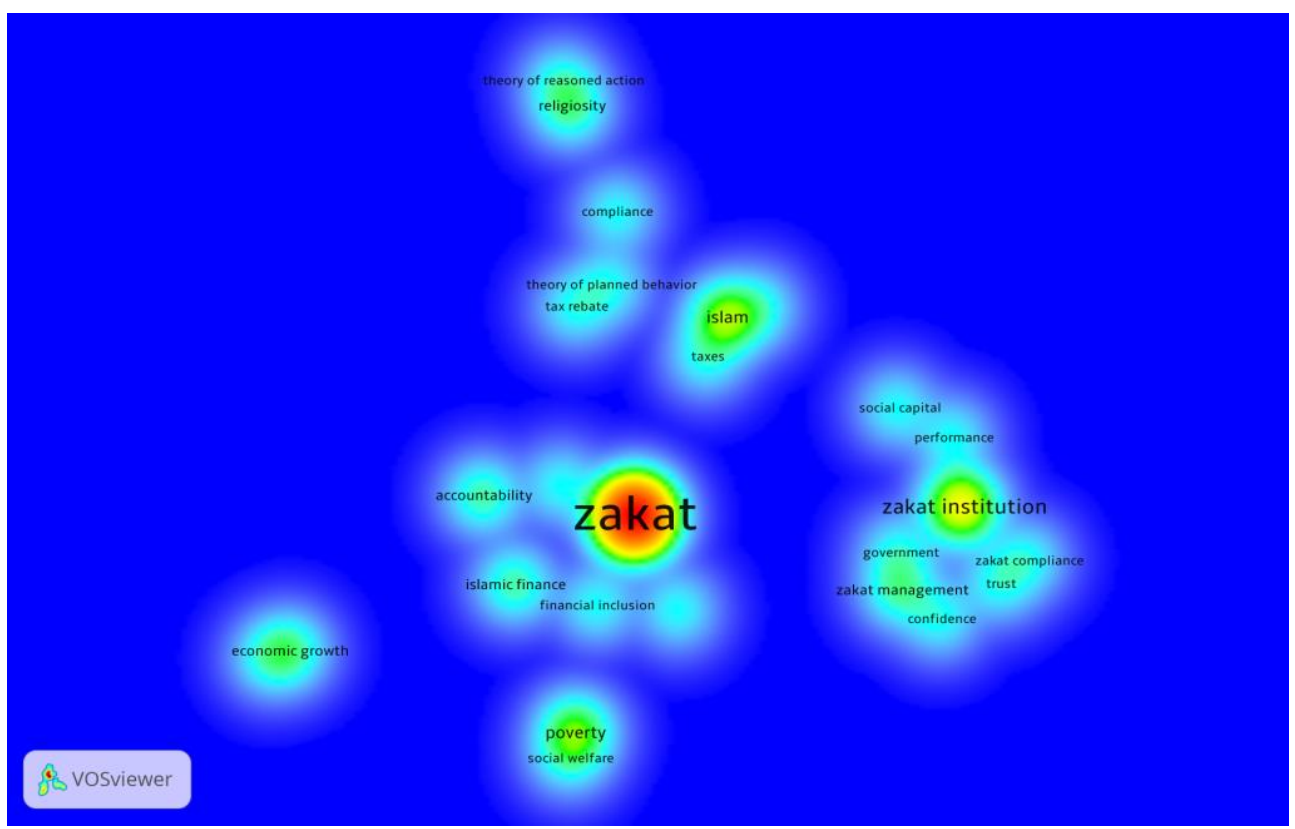

Fig 5. Density Map Visualization

\section{Conclusion}

From the results of the analysis and discussion above, several things can be concluded. First, the number of articles on zakat published in reputable journals (Q1, Q2, and Q3) has increased, especially in the last four years. Second, the Journal of Islamic Accounting and Business Research is a reputable journal that publishes the most articles in the field of zakat. Third, based on the density visualization map, the keywords that most often appear in research on zakat, include 'zakat', 'zakat institution', 'Islam', and 'poverty'. Meanwhile, research on zakat with the keyword 'compliance', 'financial inclusion', 'performance', and 'social capital' is still little studied by academics so it still has opportunities to be researched in the future. 


\section{$A I C \overline{I E B} \quad$ Annual International Conference \\ on Islamic Economics and Business, 2021}

\section{References}

Ahmed, H., \& Salleh, A. M. H. A. P. M. (2016). Inclusive Islamic financial planning: a conceptual framework. International Journal of Islamic and Middle Eastern Finance and Management, 9(2), 170-189. https://doi.org/10.1108/IMEFM-01-2015-0006

Akhyar Adnan, M., \& Barizah Abu Bakar, N. (2009). Accounting treatment for corporate zakat: a critical review. International Journal of Islamic and Middle Eastern Finance and Management, 2(1), 32-45. https://doi.org/10.1108/17538390910946258

Al-Ajmi, J., Abo Hussain, H., \& Al-Saleh, N. (2009). Decisions on capital structure in a Zakat environment with prohibition of riba: The case of Saudi Arabia. The Journal of Risk Finance, 10(5), 460-476. https://doi.org/10.1108/15265940911001376

Aziz, M. N., \& Mohamad, O. Bin. (2016). Islamic social business to alleviate poverty and social inequality. International Journal of Social Economics, 43(6), 573-592. https://doi.org/10.1108/IJSE-06-2014-0129

Beik, I. S. (2020). Menuju Sistim Zakat Mandatory. Badan Amil Zakat Nasional. https://baznas.go.id/pendistribusian/?option=com_content\&view=article\&id=3651

Bindu, N., Sankar, C. P., \& Kumar, K. S. (2019). Research collaboration and knowledge sharing in e-governance: Temporal analysis of co-author network. Transforming Government: People, Process and Policy, 13(1), 2-33. https://doi.org/10.1108/TG-032018-0022

Hudaefi, F. A., \& Beik, I. S. (2020). Digital zakāh campaign in time of Covid-19 pandemic in Indonesia: a netnographic study. Journal of Islamic Marketing, 12(3), 498-517. https://doi.org/10.1108/JIMA-09-2020-0299

Mohit, M. A., \& Nazyddah, N. (2011). Social housing programme of Selangor Zakat Board of Malaysia and housing satisfaction. Journal of Housing and the Built Environment, 26(2), 143-164. https://doi.org/10.1007/s10901-011-9216-y

Nor Paizin, M., Ab Rahman, S. M., Wahid, K. A., Nafi, M. N. A., Awang, S., \& Setapa, M. (2021). Bibliometric Analysis of Zakat Research in Scopus Database. International Journal of Zakat, 6(1), 13-24. https://doi.org/10.37706/ijaz.v6i1.253

Qardhawi, Y. (2011). Fiqh Zakat. Bogor: Pustaka Litera Antar Nusa.

Rusydiana, A. S., \& As-salafiyah, A. (2021). A Scientometric Analysis of Zakat Literature Published in times of COVID-19 Pandemic. International Journal of Zakat, 6(2), 114.

Samad, A., \& Glenn, L. M. (2010). Development of Zakah and Zakah coverage in monotheistic faiths. International Journal of Social Economics, 37(4), 302-315. https://doi.org/10.1108/03068291011025264

Sohag, K., Mahmud, K. T., Alam, F., \& Samargandi, N. (2015). Can Zakat System Alleviate Rural Poverty in Bangladesh? A Propensity Score Matching Approach. Journal of Poverty, 19(3), 261-277. https://doi.org/10.1080/10875549.2014.999974

van Eck, N. J., \& Waltman, L. (2010). Software survey: VOSviewer, a computer program for bibliometric mapping. Scientometrics, 84(2), 523-538. https://doi.org/10.1007/s11192-009-0146-3

Wahab, N. A., \& Rahim Abdul Rahman, A. (2011). A framework to analyse the efficiency and governance of zakat institutions. Journal of Islamic Accounting and Business Research, 2(1), 43-62. https://doi.org/10.1108/17590811111129508

Wahab, N. A., \& Rahim Abdul Rahman, A. (2012). Efficiency of Zakat Institutions In Malaysia: An Application of Data Envelopment Analysis. Journal of Economic Cooperation and Development, 33(1), 95-112.

World Population Review. (2021). Muslim Majority Countries 2021. https://worldpopulationreview.com/country-rankings/muslim-majority-countries 